\title{
Migrating industrial relations: migrant workers' initiative within and outside trade unions
}

Gabriella Alberti and Davide Però

Published in British Journal of Industrial Relations 2018, doi:10.1111/bjir.12308

\begin{abstract}
This article develops an embedded actors-centred framework for studying the mobilization and bargaining practices of migrant workers. This framework is applied to examine two instances of labour organizing by low-paid Latin American workers in London showing how migrant workers can develop innovative collective initiatives located at the junction of class and ethnicity that can be effective and rewarding in material and non-material terms. In particular, the article shows that while there is a growing interest on the part of established unions to represent migrant workers, their bargaining and mobilization strategies appear inadequate to accommodate the bottomup initiatives of such workers who, as a result, have started to articulate them independently. On the basis of the findings obtained, we thus argue in favour of an actor-centre framework to the study of migration and IR to better identify migrant workers' interests, identities and practices as shaped by complex regulatory and social context.
\end{abstract}

Keywords: intersectionality and organizing, migrant workers and labour renewal, mobilization and bargaining. 


\section{Introduction}

At a time of dramatic changes in work and employment, migration has profoundly transformed the composition of the workforce. Tapia \& Turner (2013:605) have suggested that unions have to move out of their comfort zone and revise their practices drawing on lessons from social movements to represent a changed workforce composed, especially at the low-end, 'by women, younger workers, ethnic and racial minorities, and to a significant extent [...] foreign born'. In this article we suggest that we too as industrial relations scholars have to rethink some of our analytical practices and adjust our approach to better reflect transformations occurring in the representation and self-organisation of workers.

This article makes the case for renewing industrial relations analysis of labour organizing by developing a framework centred around workers - conceived as embedded and relational actors - that we developed from key strengths of industrial relations, social movement and migration and ethnic studies. While past industrial relations research in the field of migrant workers has privileged institutional processes, organizational culture, union strategy and coalition-making, between established unions and community organisations (Holgate 2009; Tattersall 2008; Tapia 2013), we look at migrants' own experiences of both mobilizing and bargaining in the context of bottom-up initiatives. In doing so, we are focusing on an analytical category that has usually been excluded from traditional union research (see also Alberti et al. 2013). 
Guided by this framework and by Fairbrother \& Webster's (2008) recommendation of studying unionism in context - i.e. in a manner which is time and place specific - we then examine two instances of labour organizing by Latin American workers employed in the London low-paid service sector, namely the community-based Latin American Workers Association (LAWAS) and the independent trade union Independent Workers of Great Britain (IWGB).

Structurally the article is organised as follows. It starts by providing a contextual overview of the main employment and demographic transformations that have characterised contemporary Britain. After that, the article discusses the existing literature on workers' organising, highlighting its strengths and limitations. Then, drawing on such discussion, the article outlines our actors-centred framework. Following a section on our methodological approach the article moves on to an analytical description of two case studies of migrant workers organising. The final section presents the theoretical conclusions on the labour initiatives of low-paid migrant workers that the application of our framework has enabled us to reach.

\section{Employment Degradation and Migration Patterns in the UK}

In contextualising our cases, it is important to outline how in the last decades a growing number of jobs in the UK have been subjected to practices of outsourcing and fragmentation as a result of increased competition, marketization and strategies to reduce labour costs. The jobs most impacted by these processes such as cleaning, hospitality, health care and security are often those that tend to be populated by migrant workers (Rienzo 2016; Wills 2009; Martínez et al. 2017). The degradation of employment relations, the expansion of precarious forms of work and the fragmentation 
of workers' terms and conditions have been effectively documented in the UK (Doellgast 2012; Rienzo 2016; Rubery et al. 2005). Recent research in the cleaning sector highlighted the impact of employers' contractual and procurement practices including worsening pay and working time, poor training and career development and growing job insecurity (Grimshaw et al. 2014). The reason for using a subcontractor reflects the search for 'ultra-flexible employment forms' with staff available to work weekends and night shifts, long and antisocial hours (Grimshaw et al. 2014: 3). Migrant workers are usually deemed the best suited to fulfil requirements of 'flexibility' (Janta et al. 2009; Jiang \& Korczynski 2016; MacKenzie \& Forde 2010). Especially those recently arrived tend to rank high in employers' 'hiring queues' (Alberti 2014; McGovern 2007; Waldinger \& Lichter 2003). This new stratification of labour and migration suggests that, to better understand possibilities for collective action and potential responses by trade unions, we need to look more closely at the changing profile of the UK migrant population.

Already since the early 1990s structural transformations in the UK economy have been accompanied by significant socio-demographic changes connected to new immigration flows. Unlike those of the 1950s and 1960s the new immigrations lack a direct colonial link, as they largely originate in developing countries outside the Commonwealth as well as in the EU. Accordingly, a situation of 'superdiversity' (Vertovec 2014) characterised by a proliferation of migrants' nationalities adding to a pre-existing multiethnic context has emerged. For the most part, the new migrants since the 1990s have entered Britain as non-citizens with a variety of different, more fluid and precarious statuses (e.g. asylum seekers, students, temporary visa holders, undocumented), enjoying limited political rights. Below we discuss the organizing practices of one of 
the most significant of these new migrant groups, Latin Americans (McIlwaine et al. 2011). Like other new migrant groups, they often experience deskilling and find occupation in sectors of the economy - such as cleaning and other manual jobs - that 'local' workers reject due to their harsh and insecure conditions and low status (Kofman et al. 2009; Standing 2011; Wills et al. 2010). In terms of immigration policy, as pointed out by Wright (2017), the UK is characterised by a restrictive tradition and a heightened political salience adverse to migrants if compared to 'nations of immigrants' (e.g. Australia and Canada). Indeed, migrants constitute a central figure against which the cultural politics of the British state actively constructs and cements the British nation (Però 2013).

\section{Migrating Industrial Relations}

Despite a slow start in engaging with issues of diversity (as pointed out by Martínez Lucio \& Perrett 2009 in relation to ethnicity and by Wajcman 2000 in relation to gender), industrial relations has in recent years made significant progress in this area (e.g. Fine 2006; McGovern 2007; Milkman 2006; Tapia \& Turner 2013; McBride et al 2015; Martínez et al. 2017, see also below).

However, a few limitations still exist. One is the tendency to focus on the wider politics of British trade unions towards the inclusion of migrants into their structure and policies (Fitzgerald \& Hardy 2010; Mustichin 2012), overlooking the organizing practices and specific issues of migrant and minority workers (Alberti 2014; Holgate 2005).

The second lies in the retention of the centrality of class and economic exploitation in industrial relations at the expenses of other axes of inequalities (Martínez Lucio \& 
Connolly 2010; Connelly et al. 2014; McBride et al. 2015). In the light of the profound demographic transformations of the workforce mentioned above, it is important to avoid class reductionism in the analysis, especially if accompanied by tacit racialisation and ethnocentrism (Martínez Lucio \& Perrett 2009) - even though improvements in this respect have occurred since the critique moved by Virdee \& Grint (1994). We therefore draw on the idea of intersectionality - recently championed in the field of employment relations by McBride et al. (2015) - to avoid the shortcomings of 'class-only' approaches. Rather than seeing migrants as merely workers, we join this tradition of research rejecting the assimilation of migrants' specific conditions, needs and experiences to those of non-migrant workers (see Alberti et al. 2013; Però 2014), while acknowledging the many substantial common issues.

A third limitation concerns the tendency to overlook the socio-cultural profiles of the actors involved in labour bargaining and mobilization (see Tattersall 2008). Compared to Human Resource Management and Organizational Behaviour, industrial relations has had the merit of maintaining attention to the broader socio-political and institutional contexts of employment dynamics (Ackers \& Wilkinson 2008; Colling \& Terry 2010; Kelly 1998). However, our embedded actors-centred study shows that the fine-grained look at the cultural processes and web of relationships in which the different actors on the ground are part of (crucially including among these 'non-standard' workers and other non-union actors), further strengthens industrial relations analytical engagement with the wider context.

A fourth and final limitation of industrial relations concerns its over-institutionalist approach. With regard to the point of view of established unions and their 
responsiveness to the needs of 'new groups' of non-unionized workers, research has proved that the institutional reality is quite fluid on the ground, where some trade unions have demonstrated both resilience as well as capacity to respond to changes in the political economy and worker demographics (Gahan \& Pekarek 2013; Engeman 2015; Turner \& Cornfield 2007). Connected to that is the current sedentarist (Malkki 1992) and static framing of union membership that hinders a better realisation of the temporary, transient and transnational nature of the current workforce. This dominant framing centred on the idea of stable work identities, resonates little with the realities of temporary and precarious employment, the fragmentation of the workplace as a unitary and fixed space, and the current processes of subcontracting, outsourcing and dispersing of workers throughout different sites (Grimshaw et al. 2014; Wills 2009).

Social movement studies offer key insights to overcome these shortcomings (see also Gahan \& Pekarek 2013). Opportunity structures (Turner \& Cornfield 2008), culturalcognitive perspectives, including the role of organizational culture in mobilizing the grassroots (Tapia 2013) and 'framing' (Snow \& Benford 1992), have already been outlined as beneficial to the study of trade unions and their allies. The strand of social movements studies known as New Social Movements is particularly important as it draws attention to the significance of 'culture' not only in terms of organizational culture but also in terms of issues of identification, subjectivity, cultural politics, and emotions in relation to collective action; highlighting how social conflict extend well beyond issues of class, work, the labour movement and the state (e.g. Melucci 1989; Jasper 1997; Touraine 1981). Then, over the years this engagement with the cultural dimension of collective action has started to inform also other (more 'detached' and institutionalist) strands of social movement studies resulting in some degree of 
convergence (Nash 2010). Snow \& Benford (1992) and Gahan \& Pekarek (2013), for example, illuminated the significance of discursive framing in disputes and protests. Social Movements scholars have also highlighted the centrality of civil society as the crucial arena for the cultural and symbolic struggles of these 'new' social movements (de Bakker et al. 2013; Bartley \& Curtis 2014). Civil society is a key site where dominant attitudes can be challenged and alternative perspectives can become more accepted (including societal views on the rights of disenfranchised populations such as low-paid migrants) and subsequently reflected in policy. It is also the site where employers with direct or indirect involvement in exploitative and oppressive practices can be 'embarrassed' and made to redress such practice (e.g. Milkman 2006; Wills 2008; Però 2014).

Importantly, social movements scholars have also pointed out some of the risks that social movements and collective action face. Of particular relevance to this article are those of 'institutionalization' and 'goal displacements' (Zald \& Ash 1966), namely when formalized mechanisms of organizational sustainability and self-reproduction take priority over the original substantive goals of articulating the interest and representation of a particular group. MacKenzie et al. (2010) have discussed how such ‘institutionalization' can be avoided in the context of refugee community organisations and ethno-cultural recognition. Here we extend this focus to the field of work and industrial relations and in particular to precarious and migrant labour organizing.

A second field of study of relevance for strengthening industrial relations in the field of migrant workers is that of migration and ethnic studies where migrants' ethnocultural features and experiences, as well as broader questions of migrants' identity, 
diversity, transnationalism and integration, occupy centre stage. It is a field where the 'super-diverse' condition of contemporary society has been more fully recognized together with the consequent need for a renewed multi-dimensional analysis (Vertovec 2014). It is also a field where the 'methodological nationalism' (Wimmer \& Glick Schiller 2002) and 'sedentarism' (Malkki 1992) that shape much of contemporary social-scientific and policy thinking have been strongly critiqued.

Some recent strands have started to examine unions' ability to accommodate a diverse range of political cultures, actors and instances in the context of building wider coalitions with other social movements and communities in the field of migrant and non-standard work (McBride \& Greenwood 2009; Tattersall 2008). Others strands have focused on campaigning in favour of migrant workers' rights developed in response to the challenges posed to collective rights by the 'fragmentation of work' (Grimshaw et al. 2014). Wills (2008), for instance, has focused on the Justice for Cleaners Campaign, where marketization makes organizing problematic because even if better conditions are achieved at a single supplier, any successful organizing would price these subcontractors out of the market. She argued that on such grounds, Living Wage Campaigns offer a strategic alternative to traditional organizing as they provide unions with the opportunity to target the client organization rather than the direct employer and in so doing can be effective at improving the conditions of disenfranchised migrants.

Other scholars have similarly focused on the attempts at unionising and organizing migrants in the service economy of North American cities, in the context of broader civic coalitions about justice at work (Milkman et al. 2010; Turner \& Cornfield 2007). 
Erikson et al. (2000) showed how one effective strategy developed by the Justice for Janitors Campaign in LA - one of the internationally renowned attempts at 'organizing the unorganized' (Milkman 2006; Wills 2008) - turned an industrial relations issue into a public relations one by working with civic organizations to sensitise public opinion about the moral case against employment degradation. While such dimension of publicity through wider civil society mobilization and 'corporate campaigns' is starting to be increasingly recognised in the wider industrial relations debate on employee voice (see also Johnstone \& Ackers 2015), empirically grounded examinations remain scarce, together with in-depth studies of the involvement of migrant workers in these forms of organizing and their experiences of mobilization and bargaining.

Past research on migrant organizing and union renewal has in fact been mainly institutional in focus, privileging the point of view of trade union strategy (Milkman 2006; Holgate 2005, 2009); labour-community organisations' and their institutional rationale for coalitions (Tattersall 2008); or focusing on organizational cultures (Tapia 2013). Limited coverage still exists of migrant workers-led initiatives targeting directly justice at work, including bargaining practices. In fact, even Tapia's recent contribution (2013: 683) on sustainability and commitment of mobilization, privileges 'the internal challenges organizations face in mobilizing their members'. Tapia's approach focuses on mobilizing 'as a strategy to revitalise trade unions' over bargaining and negotiating, thus linking issues of migrant organizing to questions of unions' institutional survival. In contrast, our work looks at both mobilization and negotiation within and outside established trade unions and institutional collective bargaining mechanisms in a manner that seeks to be recognizant of the specific subjectivities and practices of the migrant workers involved. 
In this regard Milkman (2006)'s work paved the way in terms of re-thinking processes of organizational renewal highlighting the importance of the Latino and Mexican composition of the new US workforce. Milkman's research about the unique nature of the 'LA story' of union revitalisation shifted the approach from looking at migrants as victims to considering them as strategic actors for the revitalisation of the labour movement. The migrant identity of the workforce emerged as instrumental to the successes of specific campaigns such as Justice for Janitors and the Drywaller strike in the 1990s in the context of the West coast of the US. However, in order for these campaigns to succeed, a strategic outward investment from the leadership of the union into organizing migrants is necessary: 'Latino immigrants are ripe for organizing, but success is unlikely without a strong resource commitment and aggressive leadership from existing unions’ (Milkman 2006:184).

\section{An embedded actors-centred framework to study mobilizing and bargaining}

Building on the outlined strengths and limitations of contemporary industrial relations debates on migrant workers, we propose a framework to 'migrate industrial relations' that draws on social movements studies and migration and ethnic studies to examine migrant workers' organising practices. Our purpose is to better grasp the contemporary collective mobilizations and bargaining strategies of these workers. Firstly, the framework brings migrant workers into centre stage as emblematic embodiments of the contemporary transient and precarious workforce. This entails recognising the centrality of migrant labour to understand current employment dynamics, unionisation, union renewal and new forms of organizing. Secondly, it de-constructs assumptions about the assimilation of new migrant workers to white (or even to ethnic minority) 
workers as no longer analytically sustainable. Thirdly, our framework treats migrant workers as intersectional actors who have specific identities, positionalities (Alberti et al. 2013) as well as both material and non-material needs, disrupting unitarist notions of their 'community' of belonging and moving away from 'methodological ethnicity' (Glick-Schiller 2008). Fourthly, it focuses on the grassroots organizing of migrant workers, a group who has a limited footing in the national labour movement as well as in the wider receiving society but that - as we will see - is emerging as a significant and innovative employment relations actor. Overall, it is an approach to study industrial initiatives centred on migrant workers as actors embedded in wide social fields. These social fields comprise established labour organisations but crucially they also encompass a broader range of dynamic relationships that exist beyond such organisations but that are nonetheless relevant to the articulation of these workers' industrial practices. This means we have sought to avoid considering migrants as atomised and free-floating agents but strived to consider them as relational subjects.

\section{Research Methods}

The research is based on a comparative longitudinal approach spanning two decades and in particular on two cases of labour initiatives by low-paid Latin American workers in the London's service sector. Our case study approach draws on Flyvbjerg (2006) as we develop an interpretivist and explorative case study of the typology of theorygenerating rather than theory-testing, aiming to develop rich, holistic explanations of social phenomena while remaining context-specific (see also Eisenhardt 1989; Fairbrother \& Webster 2008; Piekkari et al. 2009). Our methodology is positioned within the tradition of Buroway's global ethnography (Burawoy et al. 2000), which has inspired the analysis of our combined qualitative data on migrant self-organisation 
focusing on the same community of Latin American workers in London. This methodological approach aims to contribute to studies of migrant workers that have in the main either focused on single national cases or specific workplace disputes (Connolly et al. 2014; Holgate 2005; Pearson et al. 2010).

In terms of the significance of the cases selected, our qualitative methodology does not allow for generalizability as historical, economic, institutional and socio-cultural contexts can vary considerably, especially between Western European countries like Britain and 'nations of immigrants' like Australia, Canada or the US - as pointed out by Quinlan and Lever-Tracy (1990) and more recently by Wright (2017). Our contextspecific in-depth ethnographic engagement and the historical and comparative breadth of our longitudinal research provide a grounded understanding of the organizing practices of this particular group of 'non-citizen' workers in London. This focus on the Latino migrants does not diminish our additional endeavour to offer a more general approach for the study of workers as embedded agents of mobilization, which may be applied to other communities of low-paid migrant workers as well as to non-migrant precarious workers developing grassroots labour initiatives inside and outside established unions.

The first case study draws on a multi-sited ethnography conducted by Davide Però across a number of initiatives, localities and scales. It involved, first, identifying and developing rapport with a group of Latino workers who were trying to improve their conditions and then follow them through in relation to their organizing practices. Intensive fieldwork was conducted from 2004 to 2006 with subsequent visits until 2012. It comprised participant observation and conversations, as well as semi- 
structured interviews and document collection. In relation to the subject of this article, Davide Però carried out participant observation at 34 events and conducted 31 in-depth semi-structured interviews. Fieldwork was conducted at meetings and training sessions organised by the Latin American Workers Association (LAWAS), the T\&G-Unite union, and community organizations, demonstrations, protests, marches, round tables, community events, recruiting activities as well as in cafes and pubs and in private homes. The interviews and informal conversations involved LAWAS members, T\&GUnite organizers and leaders, and some of their collaborators in a range of different initiatives. It also involved examining some of the texts that the participants and their organizations had produced.

The second case study on the Bloomsbury Campaign led by IWGB draws on fieldwork conducted between 2012 and 2014 by Gabriella Alberti. It also included documentary analysis of texts and campaign material produced by the participants, part of which has been made public (blogs, websites, articles, images, videos, Facebook posts); 10 indepth semi-structured interviews with workers, trade unionists from a migrant-led independent union, a large and officially recognised union, and community activists. The qualitative interviews were complemented by observations of public events, demonstrations and social gatherings. In both case studies pseudonyms have been used to preserve participants' anonymity. The data were analysed according to a qualitative approach, where emerging codes and categories were developed and revisited according to the main research questions about the forms of mobilization and negotiation of low- paid migrant workers (Coffey \& Atkinson 1996).

\section{Case Study 1: LAWAS}


In the early 2000s, realising that Latin American migrants were not receiving adequate support in the sphere of work from community organizations and from British trade unions a group of Latino trade unionists set up the Latin American Workers Association (LAWAS). This is a political and industrial initiative that contradicts the quiescence generally attributed to migrants (Ramakrishnan \& Bloemraad 2008). In the words of Fernando, one of LAWAS founders:

There were no [Latino] organizations specialised in labour issues and as the immigration questions [legal status etc.] gets progressively solved the urgent need for people becomes the many problems they have at work - as work is what enables them to earn their living. People have now started to become aware that they are not working under just and dignified conditions, that they are not getting a fair treatment, that they are discriminated, abused, mobbed and that everyday they have to try and improve their pay as well as their work environment.

On their part, while in principle available to Latino and other 'new migrant workers' groups, British trade unions had not until then been accessible in practice due to language barriers and limited mutual awareness and trust.

LAWAS' aim was both to support Latin American workers in individual cases and to actively participate in campaigns for social and material justice in the UK. After a few months of providing support to Latino workers in cafes and private homes, LAWAS decided to enhance its impact and to develop a more organic link with British trade unions whose sensitivity to the question of new migrant workers had started to grow 
(Wills 2009; Lagnado 2016) ${ }^{1}$. This resulted in LAWAS joining the T\&G Union and obtaining an office and basic resources. In the T\&G (later to become Unite), LAWAS grew in terms of casework activity to the point that it struggled to keep up with the demand from the Latino workers. In over a year they recruited about 1000 members who, by joining LAWAS, automatically also joined the T\&G-Unite.

LAWAS' politics was firmly grounded in an egalitarian class perspective as illustrated by Fernando:

Besides addressing some of the exploitative aspects experienced by Latinos workers in Britain, LAWAS struggles for helping the Latino workers coming out of their invisibility with dignity, not by "asking" but by "demanding". Together with other [migrant] workers organizations [...] we share the same class need.

However, LAWAS' class politics was also strongly intersectional as it featured an important concern for issues of 'ethnicity' comprising cultural and legal recognition as well as intercultural communication. It was a politics of class primarily directed at the members of a macro ethnic group, namely Latin American migrant workers. Rather than using ethnicity in essentialist ethno-nationalist terms, LAWAS deployed it mostly in a strategic (Spivak 1996), flexible and pan-ethnic (Espiritu 1992) manner so as to address and integrate a broad constituency of workers with significant linguistic and ethno-cultural affinities into a wider egalitarian project such as that expressed by the labour movement. 
LAWAS' initiatives comprised at least three interconnected strands. The first - that we could call 'contractual improvements' - was about negotiations concerning pay (often well below London's Living Wage), unfair dismissal, sick leave and annual leave entitlements (often not granted). The second focused on tackling workplace oppression such as sexual harassment, psychological maltreatment, verbal abuse, and mobbing. The third was less connected to the workplace and more to the Latin American workers' demand for 'recognition'. LAWAS was strongly engaged in promoting both the legal recognition of migrant workers' presence and the ethno-cultural recognition of Latinos as an ethnic minority. In addition, LAWAS was engaged in enhancing the visibility of Latino workers and their respectful treatment at work as well as in society more generally. As Maria, who joined LAWAS in 2009, stated:

LAWAS is about finding a space where you as worker and migrant can collectively find a voice to be recognised, to be heard in British society. It's a space... of encounter between Latinos themselves and from there with British society as well ... It's also ... a space where we are everything that we cannot be elsewhere because there is no space elsewhere for us to be vocal or exert our power.

Contrary to the common treatment of identity and culture in the literature as matters unrelated to class politics (see above and Però 2014, Tapia 2013), the examination of LAWAS shows how these matters were, in fact, of strong relevance to its labour engagements. A key instance in this respect concerns the cultural-political identity of LAWAS activists. The founders all had a history of union militancy in their countries of origin and their migration was connected to that. Their political background and 
identity had played a very strong role in their participation in LAWAS and indeed its creation. This political culture was characterised by an ambivalent attitude towards mainstream British unions perceived as having undergone a process of displacement of its original goals of protecting workers and having grown too moderate and remissive - as illustrated by Fernando.

The lack of strong union leadership in the UK has made the workers sleepy, unable to struggle, so we see a working class that has become submissive, that never fights. [...] They made workers think that in today's situation they don't need to struggle, so the unions' base became totally dormant. [...] Here [the UK] there is no struggle for workers' fundamental rights. Here they sack a worker and many times the union agrees and tells you 'no, the boss is right'. [...] Here we are being taught to do 'desktop unionism'.

While long-standing political identity and personal history of mobilization drove several activists to set up or join LAWAS, for others the most important drivers were the grievances that they or their friends and relatives were experiencing at work. Often such grievances acted as trigger for pre-existing but latent civic and political sensitivity and LAWAS as the opportunity and the means for transforming it in concrete engagement for labour justice.

LAWAS also fostered the emergence of a collective identity, conferring on members a sense of themselves as part of a supportive group, with the belief that investing in it was rewarding not just in terms of ameliorating their own material situation but also in terms of non-material and emotional rewards (Sziarto \& Leitner 2010). LAWAS gave 
its members a sense of pride and identity, an empowering feeling that they were shaping their lives and those of their fellow Latino workers and of low-paid working people more generally, despite the disadvantageous and exclusionary conditions they faced. It embedded them in a solidarity circuit that was at once a 'community of coping' (Korczynski 2003) and a community of struggle in which class and ethnicity were interwoven, making them feeling stronger as well as cared about. As Irene pointed out with regard to non-material benefits of organizing for LAWAS:

In my country I used to work with deprived communities - did a lot of social and community work there. That is my sensitivity, my key concern. There are many people like that now in London and LAWAS has enabled me to take my work with them here to a different level. To know that I'm making people aware of their rights and participate motivates me a lot.

This particular intersectional class politics of LAWAS also entailed seeking to impact in a number of different yet partly overlapping directions. The first involved - as we have seen - formally joining the trade union T\&G-Unite and the innovative campaign launched a few months later to target large outsourced contractors (employing mostly migrant cleaners). This campaign was called Justice for Cleaners, and was based on the model of the Justice for Janitors campaign that took place in the US a few years earlier (Erickson et al. 2002; Wills 2009).

At the same time, LAWAS also facilitated a more direct expression of particular views than it would have been possible through a direct affiliation to the T\&G-Unite, even though such views sometime clashed with Unite's official policy. This can be seen, for 
example, in the campaign for the regularisation of undocumented migrants 'Strangers into Citizens' that Unite fully supported, but that LAWAS publicly criticised for being too moderate as they thought it would leave out some of the most vulnerable migrants from the requested amnesty (see Però 2014; Lagnado 2016). In addition, LAWAS' intersectional politics was revealed through its active engagement also on other fronts such as the Latin American Recognition Campaign (LARC). LARC sought to promote the recognition of Latin Americans as an ethnic minority on a par of other more longstanding groups in Britain. LARC was different from the other Latin American recognition campaigns in that it had a clear egalitarian and anti-colonial character that the others lacked. While LARC's main focus was ethnic recognition, such focus was clearly expressed from a broadly socialist and anti-colonial perspective, showing again a particular intersection of class and ethnic politics and illustrating how ethnicity can be negotiated through class.

Due to discrepancies in political and organizational visions (such as those around the moderate/radical character that unionism should adopt, and those around the degree of autonomy to be allowed to represent the specific condition of the precarious migrant workers) as well as to interpersonal frictions, in 2009 the collaboration between LAWAS and Unite came to an end with the expulsion of LAWAS from Unite (see also Lagnado 2016). After that, however, LAWAS continued to exist and engage in struggles to protect low-paid migrant workers for about two years. It ceased to exist in 2012 but not without leaving an important legacy. Many of its members have in fact become involved in or inspired a number of organizations and initiatives in the sphere of migrants' rights, especially at the workplace. For instance, some members of LAWAS have become full-time organisers for Unite, Citizens UK, and community 
organizations such as LAWRs and Latin American Women Association while others have engaged in syndicalist organizations like IWW or in the more recently formed grassroots unions like IWGB (see also Kirkpatrick 2014), UVW, and CAIWU as well as a number of campaigns. It is these latter forms of labour engagements characterised by an independent, strongly committed way of directly organizing migrant workers that marks LAWAS as the pioneers of an important trend in contemporary British industrial relations, namely that of mobilizations directly led or co-led by new migrant workers. The following case study showcases one of the most significant instances of this trend.

\section{Case Study 2: The Bloomsbury Campaign}

Since July 2011 outsourced workers at Bloomsbury campus, University of London (UoL), employed as cleaners, porters, security guards, maintenance and catering workers have been involved in a range of industrial actions and social mobilizations. The outsourced workers, the majority of whom from Latin America, achieved an initial success in September 2011, as one the contractor in the cleaning department agreed on the payment of $£ 6,000$ overdue wages. Unison, the public sector union present on campus, had offered crucial organizational support to these workers until they obtained the London Living Wage in June 2012. This shows a degree of interest and commitment to representing precarious migrant workers. Soon after the initial victory that saw outsourced workers' wages going up four times, the union obtained also a recognition agreement with the cleaning contractor, including commitment to fund English classes for the migrant workers, who had started to join the branch in the summer of 2011. The outsourced migrant workers at the Bloomsbury campus have since developed further their campaign for improved terms and conditions beyond the question of pay, and this 
is when significant problems between the migrant workers members and the union branch leadership started to emerge.

In September 2012, a new informal labour mobilization effort started. This involved a range of unconventional forms of workplace organizing and high profile campaigns that extended outside traditional union structures and that demanded equal treatment with workers employed in-house. Namely, the workers contracted out to cleaning and other service companies confronted both the main employer (the University) and the succession of two external contractors in an attempt to improve their sick leave, holiday pay and pensions in line with the entitlements of those workers directly employed. As the mainstream union became unavailable to support these new demands, the outsourced workers continued to mobilize under the auspices of a newly constituted and independent union that some had co-founded. Thanks to the support of a coalition of students and activists on campus, migrant community organizations (such as the Coalition of Latin Americans in the UK) and other political actors sensitive to the plight of migrants, these workers have since conducted strikes, direct actions and an impressive media campaign that would lead to substantial results such as improved sick and holidays rights (see also The Guardian 2014).

An initial detailed plan of action for this new campaign was originally presented by the outsourced workers members of the recognised union branch (Unison) in the summer 2012, demanding funding from the union to start a new campaign beyond the Living Wage. As the union leadership rejected the proposal, the conflict between the (mostly Latino) contracted out workforce and the leadership of Unison started to develop. The workers increasingly perceived their union as failing to uphold its commitment to 
promote basic justice in order to preserve the status quo within the organization and with management, what in the literature has been referred to as 'goals displacement' (Zald \& Ash 1966). At the beginning of 2013 some of the Latino workers stood up for key positions of branch leaders, confident about their potential to win. Yet, in late February 2013 the union declared the electoral results void on the basis of complaints over procedural issues. Feeling discriminated against because of their different contractual status as well as because of being new migrant members of the branch, about 100 outsourced workers decided to leave the official union and organised themselves into a newly formed migrant-led independent union. This new independent union branch was in turn an offshoot of the union International Workers of the World (IWW), a long-standing international radical union (Kirkpatrick 2014) and involved some former LAWAS members.

Part of the tensions between the established union and the migrant workers who set up their own autonomous union highlight elements usually overlooked in the literature on migrant mobilization related to issues of identity, subjectivity, political culture, nonmaterial rewards and emotional aspects that arise from the practice of bargaining with employers. These overlooked issues appear critical more broadly to processes of unionisation as experienced by non-citizens and relatively vulnerable workers. Firstly, at the origin of the conflict between the migrant workers and the recognized union there were factors related to union democracy, institutional issues and internal norms. In this case the uneven ways in which the branch was run, decisions were taken and power was distributed in favour of the long-term British officers had a special weight. The barriers to these workers' full incorporation into the branch emerged from within the ordinary conduct of the branch meetings, both because their issues as outsourced 
workers needed further and specific consideration, and because translation issues generated lengthy meetings. As explained by Carlos, one of the IWGB organisers:

At that point (around January 2012), the committee was populated by cleaners especially from Latin America who hardly spoke any English. The branch was becoming completely bi-lingual with meetings lasting double the time and with different issues, such as non-payment of wages being discussed.

At this point we can see how procedural issues of union internal democracy discussed at length in the industrial relations literature (e.g. Hyman 2004) encounter specific challenges that relate to the 'intersectional' exclusion of workers who have a limited command of English, who are outsourced and who are new to both the working environment and to the functioning of British unions (see also Alberti et al). It is worth noticing in this regard that the initial involvement of migrant workers into the recognized public sector union was achieved largely through the groundwork of activist-students who acted as informal organisers. The profile of these organisers may be considered similar to that of the 'creative professional leaders' recruited to organise migrants in the context of LA labour campaigns such as those described by Milkman (2006). It shows how the role of these kind of 'non-rank and file intellectual outsiders' can actually be beneficial to promote grassroots mobilization if forms of affiliation between activists and rank-and-file workers emerge (including speaking a common language and political cultural affinities). The role of university doctoral students and activist intellectuals has been central to the development of campaigns with LAWAS and IWGB as well as in past efforts at organizising the cleaners in London (Nunes \& Alzaga 2010). In this sense IWGB is a hybrid union showing aspects of Milkman's 
(2006:148) comprehensive approach to organizing 'social movement style mobilization with carefully calibrated strategies that leverage the expertise of creative professional leaders outsiders and rank and file strategies'. Only with some delay the official union realised the importance of leveraging such cultural and linguistic affinities to recruit migrant workers and provided $£ 2,000$ to hire professional ESOL teachers.

The outsourced Latin American workers joined the new union facilitated by a degree of cultural-political affinity, a shared experience of workplace injustice, as well as a trusted social network. Clearly, on a pragmatic level, organizing into a branch where Spanish is the common spoken language made the Latin American workers feeling more at ease and included. However, not only were the workers united linguistically, but they appeared to share a common culture of political mobilization with its roots in popular traditions of indigenous and peasant struggles (see Lagnado 2016). This was a critical political culture that combined well with the radical social unionism of the IWW break-away union as pointed out in an interview by Miguel, a community organiser and ESOL teacher for the new independent union. This blend of industrial, community and indigenous organizing cultures facilitated the constitution of a large and diverse coalition on campus and across the city, which led to some remarkable victories for the outsourced migrant workers at Bloomsbury (see also Alberti 2016).

Through high profile campaigning deployed in combination with traditional workplace tactics such as strikes and picketing, as well as with a savvy use of social media such as Facebook, Twitter and YouTube videos realised with the student support, the campaign won critical improvements for the workers' terms and conditions. The three successful strikes by the outsourced cleaners, porters and maintenance workers in 
November 2013 were also made possible by the financial support offered by the larger community of activists, academics and other co-workers on campus (who collected about $£ 4,000$ in just a few days). The impressive donations for the strike fund, together with the solidarity shown by a range of different actors, had a profound impact on the outsourced workers' morale, who felt strongly encouraged and re-assured in their decision to engage in strike actions. Once again this shows how emotional reward and support from those offering solidarity can be crucial for migrant workers sustained involvement in labour disputes.

The November 2013 strike was followed by an immediate concession from the then contractor BBW, which offered holiday pay in line with that of directly employed staff and nearly equivalent, although still not the same, sick pay to in-house workers (IWGB Press Release, December 2013). Since the summer of 2014 a new series of public protest and legal battles were carried by the new independent union against the dismissal of the workers at the Garden Halls University Residences, many of whom were involved in the above campaign (see Alberti 2016). On that occasion, for a second time a group of outsourced migrant cleaners of the UoL did not feel supported by the recognised union and had to resort to alternative representation (by the recently established grassroots union). This is shown by the following statement of Sandra a cleaner from Bolivia:

At the time when I joined the official union I did not use to have issue with it. But (...) I became a member and that was it, that was the end, no one told me anything, at the meetings (...) none explained me or told me welcome, none told me: 'Look S., here things work in this way, this is the structure'. At least 
for three or five minutes explain me what is the structure of the organization, what do we do, what are the roles... nothing, absolutely nothing. And as I used to go there I found myself out of place.

The Bloomsbury Campaign effectively illustrates the tensions and contradictions (including 'goals displacement' - see Zald \& Ash 1966) that unions are faced with when deciding to organise a culturally, linguistically and contractually diverse workforce. It also points to the challenges that trade unions confront in workplaces characterised by multiple employers and a contractually fragmented workforce. One of the main barriers to traditional forms of bargaining for outsourced workers - like the Bloomsbury cleaners and caterers above -, stems from the fact that they cannot bargain directly with their main employer (the University of London), while their everyday working relations at work are managed and negotiated with the contractor in situ (see also Wills 2009; Grimshaw et al. 2014). Importantly, the Bloomsbury case shows how it is precisely under these very challenging circumstances and from the most vulnerable workers that highly innovative and successful collective action can emerge (cf. Milkman 2006, Alberti 2016).

\section{Discussion and Conclusions}

The two case studies, spanning almost a decade of research on the labour initiatives of low-paid Latin American migrants in London, employed an embedded actor-centred framework characterised by intersectionality to study migrant workers' mobilization and bargaining within and outside established unions. We have focused on low-paid and precarious migrant workers as central - rather than peripheral - figures in the current re-organization of work. As such we contend that the study of migrant 
grassroots initiative is of great relevance to current scholarship on organizing and union renewal and suggest 'migrating industrial relations' research towards approaches to mobilization and bargaining that are more centred around the agency of precarious 'non-standard' workers, including migrants. In this regard an 'actor-centred framework' does not mean that IR research should start with essentialised notions of 'the worker' or even 'the immigrant worker'. Rather, it means starting from an understanding of workers as intersectional, agentic subjects characterised by distinctive complex identities and multifaceted interests and needs, whose industrial actions simultaneously shape and are shaped by the specific contexts and webs of relationships in which they are embedded. In examining the agency of migrant workers' we have avoided considering them as either free-floating and atomised individuals or mere organisational reflections/embodiments. Rather, we have strived to frame them as relational subjects, embedded in dynamic webs of sociality, collectives of coping and struggle, as well as wider institutional and structural contexts.

Informed by such framework, our cases have shed light on two important matters. The first is the ambivalent relationship between established British unions and their lowpaid and precarious migrant workers members, and the second is the ability of migrant workers to respond creatively, collectively and effectively to conditions of exploitation and lack of effective representation.

With regard to the ambivalent relationship between established unions and precarious migrant workers, this situation has been highlighted by the limited scope existing within Unite for bottom-up agenda-setting initiatives led by migrant workers (Case 1), and in Unison's lack of support for the new equal treatment initiative demanded by migrant 
cleaners in the Bloomsbury campaign (Case 2). In addition, Case 2 showed how at the point of difficult confrontations with management, migrant members came to feel no longer represented by a union leadership that appeared more preoccupied to maintain political and organizational control and preserve the status quo rather than pressing for basic advances for its most vulnerable members. Both cases revealed frictions between large British unions and migrant workers, showing how difficult and fragile collaborations under one rigid organizational roof can be. Our cases also signalled a significant degree of resistance to internal structural and cultural change on the part of British unions to the point that, when innovative organizing practices across the workplace/community divide are initiated by migrant workers, they may well find no union support (a point confirmed by the recent cleaners' dispute at the LSE - see Acciari \& Però 2017). By failing to adequately represent the basic instances of lowpaid migrant workers, as they did in the cases we documented, mainstream unions are, perhaps unconsciously, pushing the process of 'union renewal' (Heery et al. 2003) on their outside, leaving it to be led by newly formed grassroots unions and campaigns such as those described here.

Besides hindering the material improvements for vulnerable migrant workers, the 'conservatism' of the officers of the established British unions can also discourage the development of leadership among lay-members as well as a fuller incorporation of migrant workers into mainstream unions - as illustrated by the Bloomsbury case, where workers were being prevented from gaining leadership positions in their Unison branch (see Moyer-Lee \& Lopez 2017). Our material also provides a sense of the racialised and ethnocentric nature of British union politics highlighted by Martínez Lucio \& Perrett (2009) and Virdee \& Grint (1994). On the basis of these insights we question if 
- when it comes to representing precarious migrant workers - established British unions are being characterised by 'goal displacement' (Zald \& Ash 1966; see above).

With regard the second matter - that of migrant workers' responses to exploitation and exclusion - our material has shown how, despite the unfavourable context outlined, these workers were able to draw creatively on themselves as a resource and respond to this disabling situation with the development of effective autonomous initiatives. As we have seen, grassroots migrants' labour initiatives like LAWAS and the Bloomsbury Campaign can achieve crucial mobilization and bargaining functions that mainstream British unions are not always able or willing to provide (see also Jiang \& Korczynski 2016). A key characteristic of these grassroots initiatives was their simultaneous relevance to both the material and non-material needs of the migrant workers. The two case studies show how the practices described did not simply reflect issues of pay and conditions, but a complex and multi-stranded response to intersecting oppressions that included exploitation, poor and precarious working conditions, deskilling, shifting legal status, lack of ethno-cultural recognition, social marginalisation and exclusion (see also Wills 2008). Issues of identity and subjectivity, social relations and sociality, political culture, non-material rewards and emotions, all played a key role in the mobilizations examined. This point contrasts with recurrent social movements studies' representation of class-based movements and collective action as being solely about material interests (see Però 2014), as well as with industrial relations' traditional concentration on the material and institutional side of workers' struggles (see Holgate 2005).

More generally, our cases have shown how grassroots migrant workers collective initiatives had the ability to represent and voice instances located at a particular 
intersection of class and ethnicity that otherwise would have not been articulated (due to the ambivalent relationship between established unions and precarious migrant workers just outlined). Accordingly, we suggest that this intersection is an important one to consider at the subjective and micro-relational level in the analysis of workers' collective initiatives, and one that the literature on union community coalitions has hitherto only partly examined because of a focus on institutional actors (e.g. Lier \& Stokke 2006; McBride \& Greenwood eds. 2009; Tattersal 2008, Holgate 2005; 2009). These initiatives and the forms of engagement that underpin them are similar to those that Tapia (2013) described in relation to community organizations and which tend to be 'relational' (i.e. involving social commitment, mutual trust and cooperation among members) rather than 'instrumental' (i.e. involving individualistic cost-benefit analysis). However, we also found that in our cases these 'relational' forms of engagements were critically underpinning bargaining and representation (functions that community organizations do not do). A final point to highlight with regard to migrant workers' grassroots initiatives is how - differently from what argued in Milkman (2006) - their emergence occurred in absence of material resources, showing how topdown institutional support from large unions is not always necessary for successful campaigns and initiatives.

Overall, our findings acquire further significance as migrants' organization is expanding inside and outside established British unions, and has been travelling beyond the two case studies considered here. In fact, the number of independent grassroots initiatives co-led by migrants in the UK similar to those discussed here is growing (see the recent establishment of UVW, and CAIWU) and with it the overall number of lowpaid migrant precarious workers becoming. Also, these new unions have begun to 
extend their representation of migrant workers beyond the Latin American community - e.g. with IWGB now also representing low-paid Polish migrants and with UVW also precarious Caribbean migrants organised (see UVW's campaign at the LSE in Acciari \& Però 2017). IWGB has in addition started to move beyond migrant workers' circles and also organize non-migrant/British precarious workers in critical sectors of the 'gig economy' such as couriers and foster carers (see the Guardian 2016). To conclude, a framework centred around workers as embedded and relational actors represents a productive avenue for contemporary industrial relations' scholarship on migrant workers and trade unions as well as more broadly on organising and labour renewal.

\section{References}

Acciari, L., and Però, D. (2017) 'Confronting precariousness, outsourcing and exploitation. Lessons from the LSE cleaners'. Discover Society, 51. URL: https://discoversociety.org/2017/12/06/on-the-frontline-confronting-precariousnessoutsourcing-and-exploitation-lessons-from-the-lse-cleaners/ (last accessed 13-3-18).

Ackers, P., \& Wilkinson, A. (2008) Industrial relations and the social sciences. The Sage Handbook of Industrial Relations, London: Sage. 53-68.

Alberti, G. (2014). 'Mobility strategies, "mobility differentials" and "transnational exit": the experiences of precarious migrants in London's hospitality jobs'. Work, employment and society, 28(6), 865-881.

Alberti, G. (2016). 'Mobilizing and bargaining at the edge of informality: the " 3 cosas campaign" by outsourced migrant workers at the University of London'. Journal of Labor and Society, 19(1), 81-103.

Alberti, G., Holgate, J., and Tapia, M. (2013). Organising migrants as workers or as migrant workers? Intersectionality, trade unions and precarious work. The International Journal of Human Resource Management, 24(22), 4132-4148.

Bartley, T. \& Curtis, C. (2014) 'Shaming the corporation: the social production of targets and the anti-sweatshop movement'. American Sociological Review, 79(4), 653-679.

Burawoy, M., Blum, J. A., George, S., Gille, Z., and Thayer, M. (2000). Global ethnography: Forces, connections, and imaginations in a postmodern world. Oakland, CA: University of California Press. 
Coffey, A. and Atkinson, P. (1996) Making Sense of Qualitative Data. London: Sage.

Colling, T. and Terry. M (2010) 'Work, the employment relationship and the field of industrial relations', in Colling T and Terry M. (eds) Industrial Relations. Chichester: Wiley. 3-25.

Connolly, H., Marino, S., \& Lucio, M. M. (2014). 'Trade union renewal and the challenges of representation: Strategies towards migrant and ethnic minority workers in the Netherlands, Spain and the United Kingdom'. European Journal of Industrial Relations, 20(1), 5-20.

De Bakker, F. G., Den Hond, F., King, B., \& Weber, K. (2013). 'Social movements, civil society and corporations: Taking stock and looking ahead'. Organization Studies, 34(5-6), 573-593.

Doellgast, V. (2012) Disintegrating democracy at work: labor unions and the future of good jobs in the service economy. Ithaca: Cornell University Press.

Eisenhardt, K. (1989) 'Building theories from case study research'. The Academy of Management Review. 14(4), 532-550.

Engeman, C. (2015). 'Social Movement Unionism in Practice'. Work Employment and Society, 29(3) 444-461.

Erickson, C. L., Fisk, C. L., Milkman, R., Mitchell, D. J., \& Wong, K. (2002). 'Justice for janitors in Los Angeles: Lessons from three rounds of negotiations'. British Journal of Industrial Relations, 40(3): 543-567.

Espiritu, Y. (1992). Asian American panethnicity. Bridging institutions and identities. Philadelphia: Temple University Press.

Fairbrother, P. and Webster, E. (2008) 'Social Movement Unionism. Questions and Possibilities’. Employee Responsibilities and Rights Journal. 20(4): 309-313.

Fine, J. (2006) Workers Centres: Organizing Communities at the Edge of the Dream. Itacha: Cornell University Press.

Fitzgerald, I. and Hardy, J. (2010). “ "Thinking outside the box?” Trade union organizing strategies and Polish migrant workers in the United Kingdom'. British Journal of Industrial Relations, 48(1): 131-150.

Flyvbjerg, B. (2006). 'Five misunderstandings about case-study research'. Qualitative inquiry, 12(2), 219-245.

Gahan, P., and Pekarek, A. (2013). 'Social movement theory, collective action frames and union theory: A critique and extension'. British Journal of Industrial Relations, 51(4), 754-776.

Glick Schiller, N. (2008) Beyond Methodological Ethnicity. IMER-MIM Working Paper 2/08. Malmö: Malmö University. 
Grimshaw, D., Cartwright, J., Keizer, A., Rubery, J., Hadjivassiliou, K., and Rickard, C. (2014). 'Coming clean: contractual and procurement practices'. Equality and Human Rights Commission Research Research Report, 96.

The Guardian (2014) (reference temporarily anonymised).

The Guardian (2016) Foster Carers Vote to Unionise in Fight for Pay and Working Rights. https://www.theguardian.com/society/2016/sep/20/foster-carers-fightworking-rights-trade-unions (accessed 2/3/2017)

Heery, E., Kelly J. and Waddington, J. (2003) 'Union Revitalization in Britain'. European Journal of Industrial Relations, 9(1): 79-97.

Holgate, J. (2005). 'Organizing migrant workers: a case study of working conditions and unionization in a London sandwich factory'. Work, Employment \& Society, 19(3), 463-480.

Holgate, J. (2009) 'Contested terrain: London's living wage campaign and the tensions between community and union organising.' In Community Unionism, pp. 4974. Palgrave Macmillan UK.

Hyman, R (2004) 'Is Industrial Relations Always Ethnocentric?' In Kaufman, B (Ed.) Theoretical Perspectives on Work and the Employment Relationship. Champaign: Industrial Relations Research Association, University of Illinois, (pp. 265-292).

Janta, H., Ladkin, A., Brown, L., and Lugosi, P. (2011) 'Employment experiences of Polish migrant workers in the UK hospitality sector'. Tourism Management, 32(5), 1006-1019.

Jasper, J. (1997). The Art of Moral Protest. Chicago: Chicago University Press.

Jiang, Z. and Korczynski, M. (2016) 'When the "unorganizable" organize: The collective mobilization of migrant domestic workers in London'. Human Relations. 69(3): 813-838.

Johnstone, S., and \& Ackers, P. (2015). Finding a Voice at Work? New Perspectives on Employment Relations. Oxford: OUP.

Kelly, J. (1998) Rethinking Industrial Relations. London: Routledge.

Kirkpatrick, J. (2014). 'The IWW Cleaners Branch Union in the United Kingdom'. In Ness, E. New Forms of Worker Organization, 233-57. Oakland: PMPress.

Kofman, E., Lukes, S., D'Angelo, A., \& Montagna, N. (2009). The equality implications of being a migrant in Britain. London: Middlesex University. http://eprints.mdx.ac.uk/5541 (last accessed on 3/4/2016).

Korczynski, M. (2003). 'Communities of coping: Collective emotional labour in service work'. Organization, 10(1): 55-79. 
Lagnado, J. (2016). 'Towards a History of the Latin American Workers Association 2002-12'. In Choudry A. \& Hlatshwayo M. (Eds.), Just Work?: Migrant Workers' Struggles Today London: Pluto Press, (pp. 106-128).

Lier, D. C., and Stokke, K. (2006). 'Maximum working class unity? Challenges to local social movement unionism in Cape Town'. Antipode, 38(4), 802-824.

MacKenzie, R., Forde, C. and Ciupijus, Z. (2012) 'Networks of support for new migrant communities’. Urban Studies, 49(3), 631-647.

Malkki, L. (1992) 'National Geographic: The Rooting of Peoples and the Territorialization of National Identity among Scholars and Refugees', Cultural Anthropology, 7(1): 24-44.

Martínez Lucio, M., and Connolly, H. (2010). 'Contextualizing voice and stakeholders: Researching employment relations, immigration and trade unions'. Journal of Business Ethics, 97(1), 19-29.

Martínez Lucio, M., Marino, S., \& Connolly, H. (2017). 'Organising as a strategy to reach precarious and marginalised workers. A review of debates on the role of the political dimension and the dilemmas of representation and solidarity'. Transfer: European Review of Labour and Research, 23(1), 31-46.

Martínez Lucio, M., and Perrett, R. (2009). 'The diversity and politics of trade unions' responses to minority ethnic and migrant workers: The context of the UK'. Economic and Industrial Democracy, 30(3): 324-347.

McBride, A. Hebson,G. and Holgate J. (2015) 'Intersectionality. Are we taking enough notice in the field of work and employment relations?'. Work, Employment and Society, 29(2): 331-341.

McBride, J., and Greenwood, I. (Eds.). (2009). Community unionism: a comparative analysis of concepts and contexts. London: Palgrave.

McDowell, L., Batnitzky, A., and Dyer, S. (2008). 'Internationalization and the spaces of temporary labour: The global assembly of a local workforce'. British Journal of Industrial Relations, 46(4): 750-770.

McGovern, P. (2007). 'Immigration, labour markets and employment relations: problems and prospects'. British Journal of Industrial Relations, 45(2): 217-235.

McIlwaine, C., Cock, J. and Linneker, B. (2011). No Longer Invisible. London: Queen Mary University of London.

Melucci, A. (1989). Nomads of the Present. London: Hutchinson Radius.

Milkman, R. (2006). L.A. Immigrant Story and the Future of the U.S. Labour Movement. New York: Russell Sage Foundation. 
Milkman, R., Bloom, J. and Narro, V. (eds.). (2010). Working for justice: The LA model of organizing and advocacy. Itacha: ILR Press/Cornell University Press.

Moyer-Lee, J. and Lopez H. (2017). 'From invisible to invincible: the story of the 3 cosas campaign', in Lazar, S ed. Where Are the Unions? London: Zed, 231-250.

Mustchin, S. (2012). 'Unions, learning, migrant workers and union revitalization in Britain'. Work, Employment and Society, 26(6), 951-967.

Nash, K. (2010) Contemporary Political Sociology. Oxford: Blackwell.

Nunes, V. and Alzaga, R. (2010) 'Organise Local, Strike Global'. In Collective Turbulence (Eds.) What would it mean to win? Oakland: PM Press, (pp. 59-65).

Pearson, R., Anitha, S., and McDowell, L. (2010). 'Striking issues: from labour process to industrial dispute at Grunwick and Gate Gourmet'. Industrial Relations Journal, 41(5): 408-428.

Però, D. (2013). 'Migrants, cohesion and the cultural politics of the state: Critical perspectives on the management of diversity'. Journal of Ethnic and Migration Studies, 39(8), 1241-1259.

Però, D. (2014). 'Class politics and migrants: Collective action among new migrant workers in Britain'. Sociology, 48(6), 1156-1172.

Però, D., and Solomos, J. (2010). 'Introduction: migrant politics and mobilization: exclusion, engagements, incorporation'. Ethnic and Racial Studies, 33(1), 1-18.

Piekkari, R., Welch, C., and Paavilainen, E. (2009). 'The case study as disciplinary convention'. Organizational research methods. 12 (3): 567-589.

Quinlan, M. and Lever-Tracy C. (1990) 'From labour market exclusion to industrial solidarity'. Cambridge Journal of Economics. 14: 159-181.

Ramakrishnan, S. K., and Bloemraad, I. (Eds.). (2008). Civic Hopes and Political Realities: Immigrants, Community Organizations, and Political Engagement. Russell Sage Foundation.

Rienzo, C (2016). Characteristics and Outcomes of Migrants in the UK Labour Market. ULR:

http://www.migrationobservatory.ox.ac.uk/resources/briefings/characteristics-andoutcomes-of-migrants-in-the-uk-labour-market/ (last accessed 30/03/16).

Rubery, J., Earnshaw, J., and Marchington, M. (2005). 'Blurring the boundaries to the employment relationship: from single to multi-employer relationships'. Marchington M., Grimshaw D., Rubery J. and Willmot H. (eds). Fragmenting work, 63-88.

Snow, D. A. and Benford, R. D. (1992). 'Master frames and cycles of protest'. Frontiers in Social Movement Theory, 133-155. 
Spivak, G.C. (1996) 'Subaltern Studies Deconstructing Historiography'. In Landry, D. and MacLean, G (eds.): The Spivak Reader. London: Routledge, 203-235.

Standing, G. (2011). The Precariat: The New Dangerous Class. A\&C Black.

Sziarto, K. M., and Leitner, H. (2010). 'Immigrants riding for justice: Space-time and emotions in the construction of a counterpublic'. Political Geography, 29(7), 381391.

Tapia, M. (2013). 'Marching to different tunes: Commitment and culture as mobilizing mechanisms of trade unions and community organizations'. British Journal of Industrial Relations, 51(4), 666-688.

Tapia, M., and Turner, L. (2013). 'Union campaigns as countermovements: mobilizing immigrant workers in France and the United Kingdom'. British Journal of Industrial Relations, 51(3), 601-622.

Tattersall, A. (2008). 'Coalitions and community unionism' Journal of Organizational Change Management, 21(4), 415-432.

Touraine, A. (1981). The Voice and the Eye. Cambridge: CUP.

Turner, L., and Cornfield, D. B. (2007). Labor in the New Urban Battlegrounds: Local Solidarity in a Global Economy, No 12. Itacha: Cornell University Press.

Vertovec, S. (2014). Super-diversity. London: Routledge.

Virdee, S., and Grint, K. (1994). Black self-organisation in trade unions. The Sociological Review, 42(2), 202-226.

Wajcman, Judy. 'Feminism facing industrial relations in Britain.' British Journal of Industrial Relations 38.2 (2000): 183-201.

Waldinger, R., and Lichter, M. I. (2003). How the Other Half works: Immigration and the Social Organization of Labor. Berkley: University of California Press.

Wills, J. (2008). 'Making class politics possible: Organizing contract cleaners in London'. International Journal of Urban and Regional Research, 32(2), 305-323.

Wills, J. (2009). 'Subcontracted employment and its challenge to labor'. Labor Studies Journal, 34(4), 441-460.

Wills, J., Datta, K., Evans, Y., Herbert, J., May, J., \& McIlwaine, C. (2010). Global cities at work. London: Pluto.

Wimmer, A., and Glick-Schiller, N. (2002). 'Methodological nationalism and beyond: nation-state building, migration and the social sciences'. Global Networks, 2(4), 301334. 
Wright, C. (2017). 'Employer Organizations and Labour Immigration Policy in Australia and the United Kingdom. The Power of Political Salience and Social Institutional Legacies'. British Journal of Industrial Relation, 55(2), 347-371.

Zald, M. and Ash, R (1966) 'Social movement organisations, decay and change'. Social Forces, 44(3), 327-341.

\footnotetext{
${ }^{1}$ A few months later, in fact, the T\&G-Unite would launch the Justice for Cleaners campaign aiming at unionizing outsourced cleaners in the City, Canary Wharf and the London Underground.
} 